\title{
PENGARUH DANA PIHAK KETIGA (DPK) DAN MODAL SENDIRI TERHADAP JUMLAH PEMBIAYAAN PADA PT. BPRS BAKTI MAKMUR INDAH
}

\author{
M. Fauzan
}

STIKOM Tunas Bangsa Pematangsiantar, Sumatera Utara-Indonesia Jalan Jendral Sudirman Blok A No. 1, 2, 3 Pematangsiantar

Email : mfauzan57@yahoo.com atau m.fauzan@stikomtb.ac.id

\begin{abstract}
Abstrak
Penelitian ini dilakukan untuk mengetahui pengaruh dana pihak ketiga dan modal sendiri terhadap jumlah pembiayaan pada PT. BPRS Bakti Makmur Indah. Dalam penelitian ini, data yang digunakan berupa data sekunder yang berbentuk time series yang berasal dari data internal perusahaan mengenai jumlah pembiayaan, dana pihak ketiga, dan modal sendiri. Adapun teknik pengumpulan data yang dilakukan adalah dengan menggunakan studi dokumentasi yang bersumber dari data laporan keuangan PT. BPRS Bakti Makmur Indah periode 2013-2015. Hasil penelitian menunjukkan bahwa variabel dependen jumlah pembiayaan dapat dijelaskan oleh variabel independen yaitu dana pihak ketiga dan modal sendiri sebesar 0.565 atau $56 \%$ dan sisanya (46\%) dijelaskan variabel lain diluar variabel yang digunakan. Secara serempak variabel dana pihak ketiga dan modal sendiri memiliki pengaruh positif terhadap penyaluran dana pembiayaan berdasarkan uji $F$ dimana $F_{\text {hitung }}>F_{\text {tabel }}$ $(14.550>3.127)$ sedangkan tingkat signifikan sebesar $0.000<0.05$.
\end{abstract}

Kata-Kata Kunci: Dana Pihak Ketiga (DPK), Modal Sendiri, Jumlah Pembiayaan 


\section{A. PENDAHULUAN}

Bank sebagai lembaga keuangan yang memiliki peran yang sangat penting dalam pembangunan bangsa. Dalam kegiatannya bank melakukan penghimpunan dana dari masyarakat atau dana dari dana pihak ketiga dalam bentuk simpanan. Selain itu bank melakukan kegiatan penyaluran dana dari pihak ketiga kepada masyarakat yang membutuhkan dana, baik itu untuk kegiatan konsumsi maupun untuk kegiatan produksi. Dalam bank syariah penyaluran dana ini lebih akrab disebut sebagai pembiayaan sedangkan pada bank konvensional sering disebut kredit (Kholisatun Ni'mah, 2015).

Bank syariah merupakan lembaga keuangan yang bertugas menghimpun dana masyarakat serta menyalurkannya dengan mekanisme tertentu. Penghimpunan dana dilakukan melalui simpanan dan investasi seperti giro wadiah, tabungan dan deposito berjangka. Sedangkan pembiayaan dilakukan dengan beberapa macam akad seperti murabahah, mudharabah, istishna', musyarakah, ijarah dan salam (Khodijah Hadiyyatul Maula, 2008).

Dana pihak ketiga adalah dana yang dihimpun bank yang berasal dari masyarakat yang terdiri dari simpanan tabungan, simapanan deposito dan simpanan giro. Sumber dana ini merupakan sumber dana terpenting bagi kegiatan operasi suatu bank dan merupakan ukuran keberhasilan bank jika mampu membiayai operasinya dari sumber dana ini. Pencairan dari sumber ini relatif paling mudah jika dibandingkan dengan sumber lainnya. Dana pihak ketiga merupakan sumber likuiditas untuk memperlancar pembiayaan yang terdapat di sisi aktiva neraca bank (Kasmir, 2006).

Modal merupakan aspek penting bagi suatu unit usaha bank karena digunakan untuk memenuhi kebutuhan dalam setiap aktivitasnya. Setiap penciptaan aktiva dapat berpotensi menciptakan keuntungan dan menimbulkan terjadinya risiko kerugian terutama yang berasal dari dana pihak ketiga. Semakin bagus sistem permodalan bank syariah maka akan membentuk kepercayaan yang kuat dari masyarakat sehingga dapat mempengaruhi keputusan nasabah dalam melakukan pembiayaan (Muhammad, 2002).

Di BPRS dana yang dihimpun dari masyarakat hanya berupa tabungan dan deposito. Berdasarkan ketentuan perundang-undangan BPRS tidak diperbolehkan menghimpun dana dari masyarakat dalam bentuk giro. BPRS juga tidak diperbolehkan bertransaksi dengan menggunakan mata uang asing (valuta asing) hanya diperbolehkan menggunakan mata uang rupiah.

Sumber dana dari dana pihak ketiga (DPK) yang dihimpun merupakan dana terbesar yang paling diandalkan oleh pihak bank (bisa 
mencapai $80 \%-90 \%$ ) dari seluruh dana yang dikelola oleh bank. Setiap kenaikan dana pihak ketiga dapat meningkatkan jumlah dana yang disalurkan kepada masyarakat (Lukman Dendawijaya, 2005).

BPRS Bakti Makmur Indah merupakan bank yang dalam kegiatan operasionalnya menggunakan prinsip syariah. BPRS ini telah mampu menjalankan fungsi dan peran utamanya yaitu sebagai lembaga intermediary atau perantara pihak yang surplus dana kepada pihak yang minus dana. Sesuai dengan fungsi pokok operasional bank syariah, BPRS ini menjalankan tiga fungsi pokok dalam kegiatan perekonomian masyarakat. Fungsi pokok tersebut yaitu fungsi pengumpulan dana (funding), fungsi penyaluran dana (financing), dan pelayanan jasa (services).

Dalam penyaluran pembiayaan, BPRS Bakti Makmur Indah mengalami peningkatan dalam jumlah dana yang disalurkan. Berikut merupakan data laporan keuangan BPRS Bakti Makmur Indah dari tahun 2013-2015 seperti yang tertera dalam tabel di bawah ini:

Tabel 1. Data Jumlah Pembiayaan, Dana Pihak Ketiga dan Modal
Sendiri PT. BPR Syariah Bakti Makmur Indah Periode 20013-2015 (Rp.000)

\begin{tabular}{|l|r|r|r|}
\hline Keterangan & \multicolumn{1}{|c|}{2013} & \multicolumn{1}{c|}{2014} & \multicolumn{1}{c|}{2015} \\
\hline Jumlah Pembiayaan & 104.614 .689 & 122.875 .876 & 120.518 .131 \\
\hline Tabungan & 47.100 .420 & 52.158 .517 & 62.104 .717 \\
\hline Deposito & 26.473 .223 & 25.041 .555 & 28.391 .595 \\
\hline Modal Sendiri & 13.605 .307 & 16.624 .820 & 20.948 .164 \\
\hline
\end{tabular}

Sumber: Data Olahan (http://www.bprsyariah.com)

Dari data di atas dapat dilihat bahwa jumlah pembiayaan yang disalurkan kepada masyarakat mengalami pasang surut. Pada tahun 2013-2014 terjadi peningkatan pembiayaan yang cukup signifikan tetapi pada tahun 2014-2015 terjadi penurunan jumlah pembiayaan di BPRS Bakti Makmur Indah. Untuk data tabungan mengalami peningkatan setiap tahunnya sedangkan deposito juga mengalami naik turun dalam pertumbuhannya, pada tahun 2013-2014 terjadi penurunan jumlah deposito dan pada tahun 2014-2015 terjadi peningkatan jumlah deposito. Untuk modal sendiri juga mengalami peningkatan setiap tahunnya.

Berdasarkan uraian-uraian di atas, maka penulis tertarik untuk mengangkat hal tersebut dalam sebuah penelitian dengan judul "Pengaruh Dana Pihak Ketiga dan Modal Sendiri Terhadap Jumlah Pembiayaan Pada PT. BPRS Bakti Makmur Indah".

\section{B. Kajian Teori}

\section{Dana Pihak Ketiga (DPK)}

Dana pihak ketiga merupakan dana yang dititipkan pada bank. Pada umumnya motivasi utama orang menitipkan dana pada bank adalah untuk 
keamanan dana mereka dan memperoleh keleluasaan untuk menarik kembali dananya sewaktu-waktu. (6) Yang termasuk dalam dana pihak ketiga yaitu tabungan, giro, dan deposito. Tetapi pada BPRS produk penghimpunan dana hanya ada dua yakni tabungan dan deposito (Muhammad Syafi'i Antonio, 2001).

Jenis-jenis Dana Pihak Ketiga (DPK) di BPRS yaitu:

a. Tabungan

Pengertian tabungan menurut UU. No. 10 tahun 1998 adalah simpanan yang penarikannya hanya dapat dilakukan menurut syarat tertentu yang disepakati, tetapi tidak dapat ditarik dengan cek, bilyet giro, dan/atau alat lain yang dipersamakan dengan itu (Redaksi Sinar Grafika, 2007).

Sedangkan menurut Adiwarman Karim (2004), tabungan syariah adalah tabungan yang dijalankan berdasarkan prinsip-prinsip syariah. Dalam hal ini, Dewan Syariah Nasional telah mengeluarkan pendapat fatwa yang menyatakan bahwa tabungan yang dibenarkan adalah tabungan berdasarkan prinsip wadiah dan mudharabah. Dalam hal ini nasabah bertindak sebagai penitip yang memberikan hak kepada bank syariah untuk menggunakan atau memanfaatkan uang atau barang titipannya, sedangkan bank syariah bertindak sebagai pihak yang dititipi dana atau barang yang disertai hak untuk menggunakan atau memanfaatkan dana atau barang tersebut. Sebagai konsekuensinya, bank bertanggung jawab terhadap pemiliknya. Di sisi lain, bank juga berhak sepenuhnya atas keuntungan dari hasil penggunaan atau pemanfaatan dana atau barang tersebut (Adiwarman Karim, 2004).

b. Deposito

Pengertian deposito menurut UU No. 10 tahun 1998 adalah simpanan yang penarikannya hanya dapat dilakukan pada waktu tertentu sesuai dengan perjanjian nasabah peminjam dengan bank (Redaksi Sinar Grafika, 2007).

Sedangkan menurut Adiwarman, deposito syariah adalah deposito yang dijalankan berdasarkan prinsip syariah. Dalam hal ini, Dewan Syariah Nasional MUI telah mengeluarkan fatwa yang menyatakan bahwa deposito yang dibenarkan adalah deposito yang berdasarkan prinsip syariah. Dalam aplikasinya, bank syariah bertindak sebagai mudharib (pengelola dana) sedangkan nasabah bertindak sebagai shahibul mal (pemilik dana). Dalam kapasitasnya sebagai mudharib, bank syariah dapat melakukan berbagai macam usaha yang tidak bertentangan dengan prinsip syariah serta mengembangkannya, termasuk melakukan akad mudharabah dengan semua pihak (Adiwarman Karim, 2004). 


\section{Modal Sendiri}

Sumber dana yang bersumber dari bank itu sendiri merupakan sumber dana dari modal sendiri, cadangan bank dan laba yang belum dibagi kepada para pemilik saham. Modal sendiri maksudnya modal setoran dari para pemegang saham. Meskipun untuk suatu usaha bank, proporsi dana sendiri ini relatif kecil apabila dibandingkan dengan total dana yang dihimpun ataupun total aktivanya, namun dana sendiri ini tetap merupakan hal yang penting untuk kelangsungan usahanya. Begitu pentingnya proporsi dana sendiri ini dibuktikan dengan adanya ketentuan dari bank sentral yang mengatur tentang proporsi minimal modal sendiri dibandingkan dengan nilai Aktiva Tertimbang Menurut Resiko (ATMR).

Proporsi ini lebih dikenal dengan rasio kecukupan modal (capital adequacy ratio- $C A R$ ). Apabila $C A R$ suatu bank terlalu rendah maka kemampuan bank tersebut untuk bertahan pada saat mengalami kerugian juga rendah. Modal sendiri akan dengan cepat habis untuk menutup kerugian, dan ketika kerugian telah melebihi modal sendiri maka kemampuan bank tersebut untuk memenuhi kewajiban kepada masyarakat menjadi sangat diragukan. Sehingga hal ini dapat menimbulkan penurunan tingkat kepercayaan masyarakat terhadap bank yang bersangkutan (Sigit Triandaru dan Totok Budidantoso, 2006).

Secara garis besar dana bank terdiri dari: (Kasmir, 2004)

a. Setoran modal dari para pemegang saham

Dalam hal ini pemilik saham lama dapat menyetor dana tambahan atau membeli saham yang dikeluarkan oleh perusahaan.

b. Cadangan bank

Cadangan bank maksudnya adalah cadangan-cadangan laba tahun lalu yang tidak dibagi kepada para pemegang saham. Cadangan ini sengaja disediakan untuk mengantisipasi laba tahun yang akan datang.

c. Laba yang belum dibagi

Maksudnya adalah laba yang belum dibagikan pada tahun yang bersangkutan, sehingga dapat dimanfaatkan sebagai modal untuk sementara waktu. Keuntungan dari modal sendiri adalah tidak perlu membayar bunga yang relatif lebih besar daripada jika meminjam ke lembaga lain. Sedangkan kerugiannya adalah membutuhkan waktu lama untuk memperoleh dana dalam jumlah besar disebabkan untuk melakukan penjualan saham bukan hal yang mudah.

\section{Pembiayaan}

Pembiayaan selalu berkaitan dengan aktivitas bisnis. Untuk itu, sebelum masuk pengertian pembiayaan, perlu diketahui apa itu bisnis. Bisnis adalah aktivitas yang mengarah pada peningkatan nilai tambah melalui proses penyerahan jasa, perdagangan atau pengolahan barang (produksi). Pelaku bisnis dalam menjalankan bisnisnya sangat 
membutuhkan sumber modal. Jika pelaku tidak memiliki modal secara cukup, maka ia akan berhubungan dengan pihak lain, seperti bank untuk mendapat suntikan dana, dengan melakukan pembiayaan.

Adapun yang dimaksud dengan pembiayaan, yaitu pendanaan yang diberikan oleh suatu pihak kepada pihak lain untuk mendukung investasi yang telah direncanakan, baik dilakukan sendiri maupun lembaga (Muhammad, 2005). Dan pembiayaan juga dapat diartikan dengan penyediaan dana atau tagihan dengan kata lain, pembiayaan adalah pendanaan yang dikeluarkan untuk mendukung investasi yang telah direncanakan (Wangsawidjaja, 2012).

Sehubungan dengan aktivitas bank syariah, maka pembiayaan merupakan sumber pendapatan bank syariah. Oleh karena itu, tujuan pembiayaan yang dilaksanakan bank syariah adalah untuk memenuhi kepentingan stakeholder, yakni:

1) Pemilik

Dari sumber pendapatan, para pemilik mengharapkan akan memperoleh penghasilan atas dana yang ditanamkan pada bank tersebut. 2) Pegawai

Para pegawai mengharapkan dapat memperoleh kesejahteraan dari bank yang dikelolanya.

3) Masyarakat

a. Pemilik dana

Sebagaimana pemilik dana, mereka mengharapkan dari dana yang diinvestasikan akan diperoleh bagi hasil.

\section{b. Debitur yang bersangkutan}

Para debitur, dengan menyediakan dana baginya, mereka terbantu guna menjalankan usahanya (sektor produktif) atau terbantu untuk mengadakan barang yang diinginkannya (pembiayaan konsumtif).

c. Masyarakat umumnya atau konsumen

Mereka dapat memperoleh barang-barang yang dibutuhkannya. 4) Pemerintah

Akibat penyediaan pembiayaan, pemerintah terbantu dalam pembiayaan pembangunan Negara, disamping itu akan diperoleh pajak (berupa pajak penghasilan atau keuntungan yang diperoleh bank dan juga perusahaan-perusahaan).

5) Bank

Bagi bank yang bersangkutan, hasil dari penyaluran pembiayaan, diharapkan bank dapat meneruskan dan mengembangkan usaha agar tetap bertahan dan meluas jaringan usahanya, sehingga semakin banyak masyarakat yang dapat dilayaninya. Dalam pelaksanaan pembiayaan, bank syariah harus memenuhi aspek syariah yaitu dalam setiap realisasi 
pembiayaan kepada para nasabah, bank syariah harus tetap berpedoman pada syariah Islam (antara lain tidak mengandung unsur maysir, gharar, dan riba serta bidang usahanya harus halal).

Aspek ekonomi, berarti disamping mempertimbangkan hal-hal syariah bank syariah tetap mempertimbangkan perolehan keuntungan baik bagi bank syariah maupun bagi nasabah bank.

\section{Metode Penelitian}

\section{Definisi Operasional}

Definisi operasional variabel adalah unsur penelitian yang memberitahukan bagaimana caranya mengukur suatu variabel. Dalam penelitian ini definisi operasional variabel yaitu:

a) Variabel terikat $(\mathrm{Y})$, yaitu variabel yang nilainya tergantung pada variabel lain. Adapun yang menjadi variabel terikat adalah jumlah pembiayaan yaitu sejumlah dana yang disalurkan PT. BPRS Bakti Makmur Indah kepada masyarakat.

b) Variabel bebas $X_{1}$, yaitu dana pihak ketiga yakni dana yang telah dihimpun PT. BPRS Bakti Makmur Indah dalam bentuk tabungan dan deposito.

c) Variabel bebas $X_{2}$, yaitu modal sendiri, yang terdiri dari setoran modal dari pemegang saham, cadangan-cadangan bank, dan laba yang belum dibagi.

\section{Jenis Data}

Dalam penelitian ini, data yang digunakan berupa data sekunder yang berbentuk time series yang berasal dari data internal perusahaan mengenai jumlah pembiayaan, dana pihak ketiga, dan modal sendiri.

\section{Teknik Pengumpulan Data}

Adapun teknik pengumpulan data yang dilakukan adalah dengan menggunakan studi dokumentasi yang bersumber dari data laporan keuangan PT. BPRS Bakti Makmur Indah periode 2013-2015.

\section{Analisis Data}

Analisis penelitian ini dilakukan secara bertahap sebagai berikut: 1) Uji Statistik Regresi Berganda

\section{a. Uji Statistik Regresi}

Regresi berganda adalah analisis regresi dengan menggunakan dua atau lebih variabel bebas. Data untuk penelitian ini diolah dengan menggunakan software SPSS.

b. Analisis Deskriptif

Analisis deskriptif digunakan untuk memberikan informasi mengenai karakteristik variabel penelitian yang utama, yaitu dengan cara data yang disusun dikelompokkan kemudian disajikan sehingga diperoleh gambaran umum tentang statistik data yaitu mean dan standar deviasi. Dari analisis terebut juga, akan diperoleh korelasi di antara variabel bebas 
M. Fauzan_Pengaruh Dana Pihak Ketiga (Dpk) Dan Modal Sendiri Terhadap Jumlah Pembiayaan Pada Pt. Bprs Bakti Makmur Indah

dan variabel terikat. Untuk dapat mengetahui kuatnya hubungan diantara ketiga variabel tersebut, maka dapat digunakan pedoman seperti yang tertera pada tabel di bawah ini:

\section{Tabel 2. Pedoman Untuk Memberikan Interpretasi Koefisien \\ Korelasi}

\begin{tabular}{|c|l|}
\hline Interval Koefisien & \multicolumn{1}{|c|}{ Tingkat Hubungan } \\
\hline $0,00-0,199$ & Sangat rendah \\
$0,20-0,399$ & Rendah \\
$0,40-0,599$ & Sedang \\
$0,60-0,799$ & Kuat \\
$0,80-1,000$ & Sangat kuat \\
\hline
\end{tabular}

c. Uji Normalitas

Uji normalitas merupakan suatu jenis uji statistik untuk menentukan apakah suatu populasi harus berdistribusi normal atau tidak. Uji ini penting dilakukan karena sebelum melakukan pengolahan data pada suatu pengamatan populasi maka populasi yang diamati tersebut berdistribusi normal.

2) Uji Asumsi Klasik

a) Uji Autokorelasi

Autokorelasi merupakan korelasi antara anggota observasi yang disusun menurut waktu dan tempat. Uji ini dilakukan dengan uji Durbin Watson (DW) yang menghasilkan DW hitung (d) dan nilai DW tabel (dL dan dU). Model regresi dikatakan tidak terdapat autokorelasi apabila nilai DW tabel berkisar antara batas dU dan 4-dU (Duwi Priyatno, 2009).

b) Heteroskedastisitas

Pengertian heteroskedastisitas adalah varian residual yang tidak konstan pada regresi sehingga akurasi hasil prediksi menjadi diragukan. Heteroskedastisitas bertujuan untuk menguji apakah dalam sebuah model regresi ketidaksamaan variance dari residual dari satu pengamatan yang lain tetap, homoskedastisitas. Jika variance berbeda, disebut heteroskedastisitas. Uji ini diprediksi dengan melihat pola titik-titik pada grafik regresi. Kriteria yang menjadi dasar pengambilan adalah sebagai berikut:

1) Jika ada pola tertentu, seperti titik yang ada membentuk suatu pola tertentu yang teratur (bergelombang, melebar, kemudian menyempit), maka terjadi heteroskedastisitas.

2) Jika tidak ada pola yang jelas, seperti titik-titik menyebar di atas dan di bawah angka 0 pada sumbu $\mathrm{Y}$, maka tidak terjadi heteroskedastisitas. 
c) Multikolinearitas

Multikolinearitas berarti antara variabel indepeden yang terdapat dalam model regresi memiliki hubungan linear yang sempurna atau mendekati sempurna (koefisien korelasinya tinggi atau bahkan 1). Model regresi yang baik seharusnya tidak terjadi korelasi yang sempurna atau mendekati sempurna di antara variabel bebas. Variabel yang menyebabkan multikolinearitas dapat dilihat dari nilai tolerance yang lebih kecil daripada 0,1 atau nilai VIF yang lebih besar daripada nilai 10 .

2) Uji Hipotesis

Yaitu mengukur hubungan/pengaruh yang terjadi antara variabel independen dengan variabel dependen. Regresi berganda dinyatakan dengan rumus:

$$
Y=a_{0}+b_{1} X_{1}+b_{2} X_{2}+\varepsilon
$$

Atau

$$
J P B=a_{0}+b_{1} D P K+b_{2} M S+\varepsilon
$$

Keterangan:

JPB = Jumlah Pembiayaan

$\mathrm{A}_{0} \quad=$ Konstanta

$b_{1}, b_{2}=$ Koefisien regresi berganda

DPK = Dana pihak ketiga

MS = Modal sendiri

$\varepsilon \quad=$ Standar error

Dalam analisis berganda ada tiga jenis kriteria ketetapan yang diuji:

a) Koefisien Determinasi $\left(R^{2}\right)$

Identifikasi determinasi berfungsi untuk mengetahui berapa besar persentase pengaruh antara variabel independen (dana phak ketiga dan modal sendiri) terhadap variabel dependen (jumlah pembiayaan). Jika $\mathrm{R}^{2}$ semakin besar, maka dapat dikatakan bahwa pengaruh variabel independen (dana pihak ketiga dan modal sendiri) besar terhadap variabel dependen (jumlah pembiayaan). Hal ini berarti model yang digunakan semakin kuat untuk menerangkan pengaruh variabel independen yang dteliti terhadap variabel dependen. Sebaliknya, jika $\mathrm{R}^{2}$ semakin mengecil maka dapat dikatakan bahwa pengaruh variabel independen (dana pihak ketiga dan modal sendiri) semakin kecil terhadap variabel dependen (jumlah pembiayaan). Hal ini berarti model yang digunakan tidak kuat untuk menerangkan pengaruh variabel independen yang diteliti terhadap variabel dependen.

b) Pengujian Parsial (Uji t)

Pengujian parsial adalah menguji secara parsial apakah setiap variabel independen memiliki pengaruh yang positif dan signifikan terhadap variabel dependen. Bentuk pengujiannya adalah sebagai berikut:

1) Jika $-t_{\text {tabel }} \leq t_{\text {hitung }} \leq t_{\text {tabel }}$, maka $H_{o}$ diterima. 
Artinya secara parsial tidak terdapat pengaruh yang positif dan signifikan dari variabel independen terhadap variabel dependen.

2) Jika - $t_{\text {hitung }}<-t_{\text {tabel }}$ atau $t_{\text {hitung }}>t_{\text {tabel }}$, maka $\mathrm{H}_{a}$ diterima.

Artinya secara parsial terdapat pengaruh yang positif dan signifikan dari variabel independen terhadap variabel dependen.

Kriteria pengambilan keputusan (KPK), yaitu:

a. $\mathrm{H}_{\mathrm{o}}$ diterima jika jika signifikansinya $>0.05$.

b. $\mathrm{H}_{\mathrm{a}}$ diterima jika jika signifikansinya $<0.05$.

c) Pengujian Serentak (Uji F)

Pengujian serentak adalah untuk melihat apakah variabel independen secara bersama-sama berpengaruh positif dan signifikan terhadap variabel dependen. Melalui uji statistik dengan langkah-langkah sebagai berikut:

1) Jika $F_{\text {hitung } \leq} F_{\text {tabel, }}$, maka $H_{0}$ diterima.

Artinya tidak terdapat pengaruh yang positif dan signifikan secara bersama-sama dari seluruh variabel independen terhadap variabel dependen.

2) Jika $F_{\text {hitung }>} F_{\text {tabel, }}$, maka $\mathrm{H}_{\mathrm{a}}$ diterima.

Artinya terdapat pengaruh positif dan signifikan secara bersamasama dari seluruh variabel independen terhadap variabel dependen.

Kriteria pengambilan keputusan (KPK):

a) $\mathrm{H}_{0}$ diterima jika jika signifikansinya $>0.05$.

b) $\mathrm{H}_{\mathrm{a}}$ diterima jika jika signifikansinya $<0.05$.

\section{Hasil dan Pembahasan}

\section{Sejarah Perusahaan}

PT. Bank Perkreditan Rakyat Syariah (BPRS) Bakti Makmur Indah dengan Kantor Pusat yang berkedudukan di Ruko Graha Niaga Citra Krian Blok 6-7, Jalan Raya Surabaya - Krian KM. 29 Krian - Sidoarjo Jawa Timur, merupakan salah satu Bank Perkreditan Rakyat Syariah pertama di Wilayah Jawa Timur yang didirikan berdasarkan permintaan umat di Jawa Timur akan Lembaga Keuangan Syariah berbentuk Bank yang dalam operasionalnya senantiasa mengacu pada dalam Alquran dan Hadis.

Pendirian PT. BPRS Bakti Makmur Indah diawali tahun 1993 yang diprakarsai oleh tokoh agama, tokoh masyarakat dan pengusaha muslim serta pejabat pemerintah seperti halnya KH. Zaki Goefron, KH. Imron Hamzah (alm), DR. H. Tjuk K Sukiadi, SE., HRP Moh. Noer, HMY Bambang Sujanto, HM. Aldjufri, HM. Saleh Aldjufri (alm), H. Makbul Thohir (alm) dan lainnya. Selama proses pendirian mengalami berbagai kendala yang tidak mudah baik dari sisi permodalan, perijinan maupun persiapan 
operasionalnya, mengingat bank syariah saat itu relatif masih baru dikenal di Indonesia, sehingga Bank Indonesia selaku Bank Sentral yang membuat kebijakan perbankan masih membutuhkan waktu yang cukup lama dalam memberikan ijin pendiriannya. Demikian juga halnya dengan masyarakat, walaupun awalnya memberikan dukungan penuh, namun dalam pelaksanaannya masih meragukan keberhasilan pendirian dan operasional PT. BPR Syariah Bakti Makmur Indah.

Pendirian PT BPR Syariah Bakti Makmur Indah disahkan sebagai badan hukum pada tanggal 9 Februari 1994 dengan mendapat ijin usaha dari Menteri Keuangan RI pada saat itu yakni bapak H. Moch. Mar'ie Muhammad dengan No. kep-024/KM.17/1994 tanggal 9 februari 1994.

Pendirian PT. BPR Syariah Bakti Makmur Indah diawali dengan modal sebesar Rp 262 juta dari modal dasar sebesar Rp 1 milyard. Pada tahun 2005 modal dasar ditingkatkan menjadi Rp. 3 milyar dengan modal disetor sebesar Rp . 1,5 milyar, yang dimiliki oleh 186 pemegang saham. Dalam tahun 2006, rasio permodalan (CAR) mencapai $25,72 \%$ dan tingkat kesehatan bank mencapai nilai 96 dengan kategori "sehat". Hingga saat ini PT BPR Syariah Bakti Makmur Indah telah membuka cabang di Jl. Raya Bebekan No. 21 Sepanjang Taman Sidoarjo Jawa Timur Indonesia. Telp. 031-7882137 (Hunting/fax. ) 031-7871461 serta telah memiliki beberapa Kantor Pelayanan Kas, antara lain:

1) Kantor Pelayanan Kas Candi di Jl. Raya Candi No. 220 Candi Sidoarj Telp. (031) 8057131.

2) Kantor Pelayanan Kas Mojokerto Jl. KH. Nawawi No. 31 Mojokerto Telp. (0321) 381557.

3) Kantor Pelayanan Kas Junwangi Pondok Pesantren Al-Amanah Ds. Junwangi Krian Sidoarjo.

4) Kantor Pelayanan Kas SMU Muhamadiyah 1 Sepanjang. Jl. Raya Ketegan 35 Sepanjang Sidoarjo.

5) Kantor Pelayanan Kas SMP Muhamadiyah 2 Sepanjang. Jl. Belakang Pasar Lama 135 Sepanjang Sidoarjo.

2. Produk-Produk PT. BPRS Bakti Makmur

Dalam menjalankan kegiatan usahanya sehari-hari PT. BPRS Bakti Makmur Indah dapat dibagi dalam beberapa jenis kegiatan yang meliputi:

a) Produk Penghimpunan Dana (Funding)

Produk-produk pengimpunan dana (funding) yang terdapat di PT. BPRS Bakti Makmur Indah, yaitu Tabungan Wadiah Haji, Tabungan Wadiah Kurban, Tabungan Wadiah Inshada, Tabungan Wadiah Qardhiyyu, Tabungan Mudharabah Umum, Tabungan Mudharabah Pelajar, Deposito Mudharabah, Deposito Mudharabah Muqayaadah, Saham Biasa dan Saham Preferens.

b) Produk Penyaluran Dana (Lending) 
Produk-produk penyaluran dana (lending) yang terdapat di PT. BPRS Bakti Makmur Indah, yaitu Pembiayaan Mudharabah, Pembiayaan Musyarakah, Pembiayaan Murabahah, Pembiayaan Istishna', Pembiayaan ljarah Muntahiya Bittamlik, Pembiayaan Al-Hiwalah dan Pinjaman Al-Qardh.

\section{Daerah Pemasaran}

Daerah pemasaran produk-produk PT. BPRS Bakti Makmur Indah meliputi Surabaya, Sidoarjo, Mojokerto dan kawasan di sekitarnya.

4. Uji Statistik Regresi Berganda

a) Uji Statistik Regresi

Regresi berganda adalah analisis regresi dengan menggunakan dua atau lebih variabel bebas. Data untuk penelitian ini diolah dengan menggunakan software SPSS versi 17.00 dengan melihat dan mengestimasi parameter variabel yang akan diamati dari model yang telah ditetapkan. Setelah mendapatkan estimasi model tersebut, maka akan dilakukan dengan uji statistik, yaitu uji statistik regresi pada kenormalan.

b) Uji Analisis Deskriptif

Statistik deskriptif adalah statistik yang berhubungan dengan pengumpulan data. Data dalam penelitian ini, penulis peroleh dari data laporan keuangan PT. BPR Syariah Bakti Makmur Indah yakni dana pihak ketiga, modal sendiri dan jumlah pembiayaan, kemudian data diolah dengan hasil dari studi dokumentasi. Dalam penelitian ini penulis hanya ingin melihat pengaruh di antara masing-masing variabel yakni dana pihak ketiga dan modal sendiri terhadap jumlah pembiayaan.

c) Uji Normalitas

Data variabel yang baik adalah data yang memiliki kurva dengan kemiringan sisi kiri dan kanan, dan tidak condong ke kiri maupun ke kanan, melainkan ke tengah dengan bentuk seperti lonceng dengan mendekati nol.

Dengan melihat tampilan grafik histogram maupun grafik normal plot dapat disimpulkan bahwa grafik histogram memberikan pola distribusi yang mendekati normal. Sedangkan pada grafik normal plot terlihat titiktitik menyebar di sekitar garis diagonal, serta penyebarannya mengikuti arah garis diagonal. Kedua grafik ini menunjukkan bahwa model regresi layak dipakai karena memenuhi asumsi normalitas.

5. Uji Asumsi Klasik

a) Autokorelasi

Autokorelasi sering dikenal dengan nama korelasi serial, dan sering ditemukan pada data serial waktu (time series). Regresi yang terdeteksi autokorelasi dapat berakibat biasanya pada interval kepercayaan dan ketidaktepatan penerapan uji $\mathrm{F}$ dan uji t. Untuk uji asumsi klasik autokorelasi dapat dilihat pada tabel model summary yaitu pada kolom D- 
W atau Durbin Watson yang menunjukkan D-Wnya adalah 1.41 dan untuk $\mathrm{D}-\mathrm{W}$ tabel pada $\mathrm{p}$ value $=0.05$ dengan $\mathrm{N}=36$. Maka akan didapatkan nilai sebagai berikut:

Table 3. Model Summary ${ }^{b}$ Durbin Watson Model Summary ${ }^{b}$

\begin{tabular}{|c|c|c|c|c|c|}
\hline Model & $\mathrm{R}$ & $\begin{array}{c}\mathrm{R} \\
\text { Square }\end{array}$ & $\begin{array}{c}\text { Adjusted } \\
\text { R } \\
\text { Square }\end{array}$ & $\begin{array}{l}\text { Std. } \\
\text { Error of } \\
\text { the } \\
\text { Estimate }\end{array}$ & $\begin{array}{l}\text { Durbin- } \\
\text { Watson }\end{array}$ \\
\hline 1 & $.709^{a}$ & 0.512 & 0.462 & 0.04217 & 2.31 \\
\hline
\end{tabular}

Tabel 4. Durbin Watson

\begin{tabular}{|c|c|c|}
\hline & $\mathrm{K}=2$ & \\
\hline $\mathrm{N}$ & $4-\mathrm{du}$ & $\mathrm{Du}$ \\
\hline 36 & 2.4276 & 1.5886 \\
\hline
\end{tabular}

Karena nilai DW 2.31 dan terletak diantara (du) 1.5886 dan (4-du) 2.4276, maka dapat disimpulkan tidak terdapat autokorelasi positif pada model regresi, atau model regresi memenuhi persyaratan asumsi klasik tentang autokorelasi.

b) Heteroskedastisitas

Pengertian heteroskedastisitas adalah varian residual yang tidak konstan pada regresi sehingga akurasi hasil prediksi menjadi diragukan. Heteroskedastisitas dapat diartikan sebagai ketidaksamaan variasi variabel pada semua pengamatan dan kesalahan yang terjadi memperlihatkan hubungan yang sistematis sesuai dengan besarnya satu atau lebih variabel bebas sehingga kesalahan tersebut tidak random (acak). Residual pada heteroskedastisitas semakin besar apabila pengamatan semakin besar. Demikian juga pengamatan variabel bebas $x$ yang semakin besar akan memperbesar rata-rata residu.

Dari grafik Scatterplot terlihat titik-titik menyebar secara acak serta tersebar baik di atas maupun di bawah angka 0 pada sumbu Y. Hal ini dapat disimpulkan bahwa tidak terjadi heteroskedastisitas pada model regresi, sehingga model regresi layak dipakai untuk memprediksi penyaluran dana pembiayaan berdasarkan masukan variabel bebas dana pihak ketiga dan modal sendiri.

c) Multikolinearitas

Multikolinearitas dapat dideteksi pada model regresi apabila antara variabel independen yang terdapat dalam model regresi memiliki hubungan linear yang sempurna atau mendekati sempurna (koefisien korelasinya tinggi atau bahkan 1). Di samping itu, multikolinearitas dapat 
menyebabkan fluktuasi yang besar pada prediksi koefisien regresi, dan juga dapat menyebabkan penambahan variabel independen yang tidak berpengaruh sama sekali.

Tabel 5. Coefficients ${ }^{a}$ Multikolinearitas Coefficients $^{a}$

\begin{tabular}{|c|c|c|c|c|c|c|c|}
\hline \multirow[b]{2}{*}{ Model } & \multicolumn{2}{|c|}{$\begin{array}{c}\text { Unstandardized } \\
\text { Coefficients }\end{array}$} & \multirow{2}{*}{$\begin{array}{c}\text { Standardized } \\
\text { Coefficients } \\
\text { Beta }\end{array}$} & \multirow[b]{2}{*}{$t$} & \multirow[b]{2}{*}{ Sig. } & \multicolumn{2}{|c|}{$\begin{array}{l}\text { Collinearity } \\
\text { Statistics }\end{array}$} \\
\hline & B & $\begin{array}{l}\text { Std. } \\
\text { Error }\end{array}$ & & & & Tolerance & VIF \\
\hline 1 (Constant) & 9.854 & 1.161 & & 8.485 & 0 & & \\
\hline Dpk & 0.339 & 0.086 & 0.663 & 3.926 & 0 & 0.547 & 1.776 \\
\hline Mdl & 0.006 & 0.016 & 0.065 & 0.383 & 0.704 & 0.547 & 1.776 \\
\hline
\end{tabular}

Dari data di atas diketahui, hasil perhitungan nilai toleransi menunjukkan bahwa tidak ada variabel bebas yang memiliki nilai toleransi lebih kecil dari 0,1 . Untuk variabel dana pihak ketiga nilai toleransinya sebesar 0,547 atau sekitar $54,7 \%$ sedangkan untuk variabel modal sendiri memiliki nilai toleransi sebesar 0,547 atau sekitar 54,7\% yang berarti tidak terdapat korelasi antara variabel bebas.

Hasil perhitungan nilai variance inflation factor (VIF) juga menunjukkan hal yang sama, tidak satu variabel bebas yang memiliki nilai VIF lebih dari 10. Untuk variabel dana pihak ketiga memiliki nilai VIF sebesar 1.776 sedangkan untuk variabel modal sendiri memiliki nilai VIF sebesar 1.776. Jadi, dapat disimpulkan bahwa tidak terdapat multikolinearitas antara variabel bebas dalam model regresi.

6. Uji Hipotesis

a) Uji Koefisien Determinasi $\left(R^{2}\right)$

Analisis regresi adalah salah satu jenis analisis parametrik yang dapat memberikan dasar untuk memprediksi serta menganalisis varian. Sedangkan tujuan analisis regresi secara umum adalah menentukan garis regresi berdasarkan nilai konstanta dan koefisien regresi yang dihasilkan, mencari korelasi bersama-sama antara variabel terikat dan menguji signifikansi pengaruh antara variabel bebas dan terikat.

\section{Tabel 6. Model Summary ${ }^{b}$ Koefisien Determinasi} Model Summary ${ }^{b}$

\begin{tabular}{|c|c|c|c|c|}
\hline Model & $\mathrm{R}$ & $\begin{array}{c}\mathrm{R} \\
\text { Square }\end{array}$ & $\begin{array}{c}\text { Adjusted } \\
\text { R } \\
\text { Square }\end{array}$ & $\begin{array}{l}\text { Std. } \\
\text { Error of } \\
\text { the } \\
\text { Estimate }\end{array}$ \\
\hline 1 & $.752^{\mathrm{a}}$ & 0.565 & 0.472 & 0.04226 \\
\hline
\end{tabular}


Dari hasil output di atas tersebut memiliki nilai koefisien determinasi $\left(R^{2}\right)$ menunjukkan bahwa nilai $R=0.752$ dan $R \times R=R^{2}$ sebesar 0.565 atau $56 \%$ artinya bahwa variabel terikat pada penyaluran dana pembiayaan mampu dijelaskan oleh variabel bebas yakni dana pihak ketiga dan modal sendiri sebesar $56 \%$ dan sisanya (46\%) dijelaskan variabel lain diluar variabel yang digunakan.

Kolom standard error if the istimate (SEE) yang terdapat pada model summary ${ }^{b}$ merupakan output yang berfungsi untuk melihat seberapa besar prediksi dari tingkat kesalahan dari model regresi berganda yang ada. Dimana jika nilai SEEnya semakin kecil maka prediksi yang dilakukan terhadap variabel dependen akan semakin baik.

Nilai SEEnya sebesar 0.04226, yang artinya bahwa tingkat kesalahan yang mungkin terjadi adalah sebesar 0.04226. Jadi dapat disimpulkan, bahwa dari model regresi berganda layak dipakai untuk penelitian, karena sebagian variabel terikat dijelaskan oleh variabel bebas yang digunakan dalam model.

b) Uji Parsial (Uji t Statistik)

Uji t dapat dilihat pada tabel coefficients (a) yang bertujuan untuk mengetahui besarnya pengaruh masing-masing variabel bebas secara individual terhadap variabel terikat. Uji t tersebut dibutuhkan untuk menguji seberapa besar pengaruh variabel bebas yakni dana pihak ketiga dan modal sendiri terhadap penyaluran dana pembiayaan.

Tabel 7. Coefficients ${ }^{\text {a }}$ T-Test Statistik

coefficients $^{\mathrm{a}}$

\begin{tabular}{|c|c|c|c|c|r|}
\hline & \multicolumn{2}{|c|}{$\begin{array}{c}\text { Unstandardized } \\
\text { Coefficients }\end{array}$} & $\begin{array}{c}\text { Standardized } \\
\text { Coefficients }\end{array}$ & & \\
\cline { 2 - 4 } Model & $\mathrm{B}$ & $\begin{array}{c}\text { Std. } \\
\text { Error }\end{array}$ & Beta & \multicolumn{1}{|c|}{ T } & \multicolumn{1}{|c|}{ Sig. } \\
\hline $1 \quad$ (Constant) & 8.756 & 1.161 & & 8.485 & 0 \\
Dpk & 0.224 & 0.086 & 0.663 & 3.127 & 0 \\
Mdl & 0.008 & 0.016 & 0.065 & 0.286 & 0.704 \\
\hline
\end{tabular}

Pengujian dana pihak ketiga pada uji t dapat dilihat pada tabel coeffisients $^{a}$ yaitu pada kolom $\mathrm{T}$ yang menunjukkan nilai $t_{\text {hitung }}$ adalah 3.926 dan untuk $t_{\text {tabel }}$ pada $\alpha=0.05$ dengan $\mathrm{N}-\mathrm{K}$. N adalah jumlah variabel bebas maka, 36 - $2=34$ maka pada $t_{\text {tabel }}$ akan didapatkan nilai sebagai berikut: 
Tabel 8. T TABEL STATISTIK

\begin{tabular}{|c|c|}
\hline \multicolumn{2}{|c|}{ Uji Dua Arah } \\
\hline $\mathrm{N}$ & 0.05 \\
\hline 34 & 2.14 \\
\hline
\end{tabular}

Dari data di atas diketahui bahwa, variabel dana pihak ketiga memiliki nilai $\mathrm{p}$-value $0<0.05$ yang berarti signifikan, sedangkan $t_{\text {hitung }}$ $3.127>t_{\text {tabel }} 2.14$ artinya signifikan. Maka dana pihak ketiga secara parsial berpengaruh terhadap penyaluran dana pembiayaan, atau Ha diterima.

Sedangkan pengujian modal sendiri pada uji t dapat dilihat pada tabel coeffisients ${ }^{a}$ yaitu pada kolom $T$ yang menunjukkan nilai $t_{\text {hitung }}$ adalah 0.286 dan untuk tabel pada $\alpha=0.05$ adalah 2.14. Jadi dapat diketahui bahwa, variabel modal sendiri memiliki nilai $p$-value $0.704>0.05$ yang berarti tidak signifikan, sedangkan $t_{\text {hitung }} 0.286<$ dari $t_{\text {tabel }} 2.14$ artinya tidak signifikan. Maka modal sendiri secara parsial tidak berpengaruh terhadap penyaluran dana pembiayaan atau Ho diterima.

Dari hasil uji t di atas, dinyatakan bahwa semua variabel bebas yaitu dana pihak ketiga dan modal sendiri dapat dilambangkan dengan rumus:

$$
Y=a_{0}+b_{1} X_{1}+b_{2} X_{2}+\varepsilon
$$

Atau

$$
\begin{gathered}
\mathrm{Y}=\mathrm{a}_{0}+\mathrm{b}_{1} \mathrm{DPK}+\mathrm{b}_{2} \mathrm{MS}+\varepsilon \\
\mathrm{Y}=8.756+0.224 \mathrm{DPK}+0.008 \mathrm{MS}
\end{gathered}
$$

Konstanta $(a)=8.756$, artinya jika dana pihak ketiga dan modal sendiri tidak dimasukkan dalam penyaluran pembiayaan maka pembiayaan sebesar 8.756 . Koefisien regresi $D P K=0.224$, artinya jika dana pihak ketiga yang mempengaruhi pembiayaan naik sebesar $R p 1$, maka pembiayaan akan naik sebesar $\mathrm{Rp} 0.224$. Koefisien regresi $\mathrm{MS}=$ 0.006 , artinya jika apabila variabel modal sendiri naik sebesar $\mathrm{Rp} 1$, maka akan mempengaruhi pembiayaan sebesar Rp 0.006.

c) Uji Secara Serempak (Uji F Statistik)

Uji simultan $\mathrm{F}$ adalah bertujuan untuk mengetahui pengaruh variabel bebas secara bersama-sama terhadap variabel terikat. Untuk uji F dapat dilihat pada tabel Anova berikut. 
Tabel 9. Anova ${ }^{a}$ F-test Statistik ANOVA $^{\text {b }}$

\begin{tabular}{|c|c|c|c|c|c|c|}
\hline \multicolumn{2}{|c|}{ Model } & $\begin{array}{l}\text { Sum of } \\
\text { Squares }\end{array}$ & Df & $\begin{array}{l}\text { Mean } \\
\text { Square }\end{array}$ & $\mathrm{F}$ & Sig. \\
\hline 1 & Regression & .056 & 2 & .028 & 14.550 & $.000^{a}$ \\
\hline & Residual & .056 & 33 & .002 & & \\
\hline & Total & .112 & 35 & & & \\
\hline
\end{tabular}

a. Predictors: (Constant), mdl, dpk

b. Dependent Variable: PBYmurabahah

Pengujian pengaruh variabel bebas secara serempak terhadap variabel terikat dapat dilihat pada tabel $A N O V A^{b}$ yaitu pada kolom $\mathrm{F}$ yang menunjukkan nilai $F_{\text {hitung }}$ adalah 14.550 dan untuk $F_{\text {tabel }}$ pada $\alpha=0.05$ dengan df 1 (jumlah variabel -1 ) atau 3-1 = 2, dan df 2 (n-k-1) atau 36-2-1 $=33$ maka di $F_{\text {tabel }}$ akan didapatkan nilai sebagai berikut:

Tabel 10. F TABEL STATISTIK

\begin{tabular}{|c|c|}
\hline \multicolumn{2}{|c|}{ Uji Dua Arah } \\
\hline $\mathrm{N}$ & 2 \\
\hline 33 & 3.172 \\
\hline
\end{tabular}

Dari uji ANOVA atau F-test statistik menunjukkan p-value $0.000<$ 0.05 , artinya signifikan, sedangkan $F_{\text {hitung }} 14.550>3.172$, artinya signifikan. Signifikan di sini berarti Ha diterima, artinya dana pihak ketiga dan modal sendiri secara bersama-sama berpengaruh terhadap penyaluran dana pembiayaan. Dapat disimpulkan bahwa model regresi dapat dipakai untuk memprediksi penyaluran dana pembiayaan.

\section{E. Kesimpulan}

\section{Kesimpulan}

Berdasarkan hasil pembahasan diatas, penelitian ini dapat disimpulkan yaitu:

1) Variabel dependen jumlah pembiayaan dapat dijelaskan oleh variabel independen yaitu dana pihak ketiga dan modal sendiri sebesar 0.565 atau $56 \%$.

2) Secara parsial variabel dana pihak ketiga memiliki pengaruh terhadap variabel penyaluran dana pembiayaan berdasarkan uji $t$ dimana $t_{\text {hitung }}>t_{\text {tabel }}(3.127>2.14)$ sedangkan tingkat signifikan sebesar $0<0.05$. Hal ini berarti hipotesis $\mathrm{H}_{a}$ diterima, artinya secara parsial variabel dana pihak ketiga berpengaruh terhadap pembiayaan. Sedangkan untuk variabel modal sendiri berdasarkan uji $t$ dimana $t_{\text {test }}<t_{\text {tabel }}(0.286<2.14)$ dengan tingkat signifikan 
sebesar $0.704<0.05$. Hal ini berarti Ho diterima, artinya secara parsial variabel modal sendiri tidak berpengaruh terhadap pembiayaan.

3) Secara serempak variabel dana pihak ketiga dan modal sendiri memiliki pengaruh positif terhadap penyaluran dana pembiayaan berdasarkan uji $F$ dimana $F_{\text {hitung }}>F_{\text {tabel }}(14.550>3.127)$ sedangkan tingkat signifikan sebesar $0.000<0.05$. Hal ini berarti hipotesis $\mathrm{H}_{a}$ diterima, artinya semakin baik dana pihak ketiga dan modal sendiri maka semakin meningkatkan jumlah pembiayaan pada PT. BPR Syariah Bakti Makmur Indah.

\section{DAFTAR RUJUKAN}

Antonio, Muhammad Syafi'i. 2001. Bank Syariah dari Teori ke Praktek. Gema Insani. Jakarta.

Dendawijaya, Lukman. 2005. Manajemen Perbankan. Ghalia Indonesia. Bogor.

Maula, Khodijah Hadiyyatul. 2008. Skripsi: Pengaruh Simpanan (Dana Pihak Ketiga), Modal Sendiri, Margin Keuntungan dan Non Performing Financing Terhadap Pembiayaan Murabahah Pada Bank Syariah Mandiri. Fakultas Syariah UIN Sunan Kalijaga. Yogyakarta.

Muhammad. 2002. Manajemen Bank Syariah. UPP AMP YKPN. Yogyakarta.

Muhammad. 2005. Manajemen Pembiayaan Bank Syariah. UPP AMP YKPN. Yogyakarta.

Ni'mah, Kholisatun. 2015. Skripsi: Analisis Pengaruh Dana Pihak Ketiga (DPK), Modal Sendiri, Return On Asset (ROA) dan Financing To Deposit Ratio (FDR) Terhadap Pembiayaan yang Disalurkan Pada BRI Syariah pada Tahun 2010-2014. Fakultas Ekonomi dan Bisnis Islam UIN Walisongo. Semarang.

Karim, Adiwarman. 2004. Analisis Fiqh dan Keuangan. PT. Rajagrafindo Persada. Jakarta.

Kasmir. 2004. Pemasaran Bank. Kencana. Jakarta.

Kasmir. 2006. Dasar-Dasar Perbankan. PT. Rajagrafindo Persada. Jakarta. 
M. Fauzan_Pengaruh Dana Pihak Ketiga (Dpk) Dan Modal Sendiri Terhadap Jumlah Pembiayaan Pada Pt. Bprs Bakti Makmur Indah

Priyatno, Duwi. 2009. 5 Jam Belajar Olah Data dengan SPSS 17. Andi. Yogyakarta.

Redaksi Sinar Grafika. 2007. Undang-Undang Perbankan No. 10 Tahun 1998. Sinar Grafika. Jakarta.

Triandaru, Sigit dan Budidantoso, Totok. 2006. Bank dan Lembaga Keuangan Lain. Salemba Empat. Jakarta.

Wangsawidjaja. 2012. Pembiayaan Bank Syariah. PT. Gramedia Pustaka. Jakarta. 